\title{
Chrysomya albiceps (Wiedemann) and Hemilucilia segmentaria (Fabricius) (Diptera, Calliphoridae) used to estimate the postmortem interval in a forensic case in Minas Gerais, Brazil
}

\author{
Cecília Kosmann¹, Marcos Patrício Macedo², Thiago Assis Franco Barbosa ${ }^{3}$ \& José Roberto Pujol-Luz ${ }^{1}$
}

\begin{abstract}
1Departamento de Zoologia, Universidade de Brasília, 70910-900 Brasília-DF, Brazil. ceciliakosmann@gmail.com; jrpujol@unb.br ${ }^{2}$ Instituto de Pesquisa de DNA Forense, Bloco E, SAI, 70610-200 Brasília-DF, Brazil. marcos.patricio@gmail.com

${ }^{3}$ Primeira Delegacia Regional de Polícia Civil Unaí, $16^{\circ}$ Departamento de Polícia Civil, Seção Regional Técnica de Criminalística, $38610-000$ UnaíMG, Brazil. thiagoafb@yahoo.com.br
\end{abstract}

\begin{abstract}
Chrysomya albiceps (Wiedemann) and Hemilucilia segmentaria (Fabricius) (Diptera, Calliphoridae) used to estimate the postmortem interval in a forensic case in Minas Gerais, Brazil. The corpse of a man was found in a Brazilian highland savanna (cerrado) in the state of Minas Gerais. Fly larvae were collected at the crime scene and arrived at the laboratory three days afterwards. From the eight pre-pupae, seven adults of Chrysomya albiceps (Wiedemann, 1819) emerged and, from the two larvae, two adults of Hemilucilia segmentaria (Fabricius, 1805) were obtained. As necrophagous insects use corpses as a feeding resource, their development rate can be used as a tool to estimate the postmortem interval. The post-embryonary development stage of the immature collected on the body was estimated as the difference between the total development time and the time required for them to become adults in the lab. The estimated age of the maggots from both species and the minimum postmortem interval were four days. This is the first time that $H$. segmentaria is used to estimate the postmortem interval in a forensic case.
\end{abstract}

KEYWORDS. Blowflies; Brazilian savannah; Forensic Entomology; postmortem interval.

RESUMO. Chrysomya albiceps (Wiedemann) e Hemilucilia segmentaria (Fabricius) (Diptera, Calliphoridae) utilizadas para estimar o intervalo pós-morte em um caso forense em Minas Gerais, Brasil. O cadáver de um homem foi encontrado em uma área de cerrado no Estado de Minas Gerais. Larvas de moscas foram coletadas na cena do crime e encaminhadas ao laboratório em três dias. Os adultos que emergiram em laboratório foram identificados como Chrysomya albiceps (Wiedemann, 1819) e Hemilucilia segmentaria (Fabricius, 1805). Uma vez que insetos utilizam o cadáver como uma fonte de recurso alimentar, sua taxa de desenvolvimento pode ser empregada como uma ferramenta para estimar o intervalo pós-morte. O estágio de desenvolvimento pós-embrionário dos imaturos coletados no cadáver foi estimado como sendo a diferença entre o tempo total de desenvolvimento e o tempo necessário para a emergência destes adultos em laboratório. A idade estimada dos imaturos das duas espécies, bem como o intervalo pós-morte mínimo, foi de quatro dias. Este é o primeiro relato do uso de Hemilucilia segmentaria para estimar o intervalo pósmorte em um caso forense.

PALAVRAS-CHAVE. Moscas-varejeiras; Cerrado; Entomologia Forense; intervalo Pós-morte.

The family Calliphoridae consists of calyptrate muscoids commonly known as blowflies, and has worldwide distribution (Vargas \& Wood 2010). They use protein-rich substrates for oviposition, seeking the full development of immature stages (Stevens 2003) and constitute the most common type of insect evidence collected during the criminal investigation (Keh 1985; Catts \& Haskell 1990). They may be the first organisms to arrive at a corpse after death, attracted by the odor produced in the early stages of decomposition (Goddard \& Lago 1985; Smith 1986; Wall \& Warnes 1994) and their activity may accelerate the decay and disintegration of the body (Mann et al. 1990). The determination of the species found in this type of investigation is the first step in a forensic-entomological analysis, because error in the investigation may lead to obstruction of justice (Gerber 1987; Pujol-Luz et al. 2008).
In this paper, we describe a forensic entomology case in Minas Gerais (southeastern Brazil), in which the necrophagous blow fly Hemilucilia segmentaria (Fabricius, 1805) was used for the first time, associated with Chrysomya albiceps (Wiedemann, 1819), to estimate the postmortem interval (PMI), being therefore characterized as an additional species of forensic interest.

Case Description. On 17 March 2010 the corpse of a male adult was found in a transition zone between an urban and a rural area, about five miles from the city of Unaí, northwestern Minas Gerais, Brazil (16²3'59'S, 4653'37'W). The body was located in a marginal area of a highway, about 300 meters away from the road, in an area of Cerrado (savannah-like formation).

The corpse was found wearing shorts and a t-shirt and was partially exposed to the sun. The body had partially skel- 
etonized skull and chest, and the abdomen and upper and lower limbs in a state of gaseous decomposition. The crime scene investigators observed the presence of two gunshot wounds in the chest. There was also a total or partial amputation of hands and feet; all the teeth, ears, nose and eyes had been removed, making it impossible to identify the victim through fingerprints or other common characteristics.

A few blowfly larvae were collected at the crime scene, placed in a vial with rotten meat and sent, by car, to the Universidade de Brasília to estimate the PMI, arriving at the laboratory on 20 March 2010. During the three days that the larvae remained in possession of the police at the Police station, they were kept at room temperature, which was approximately $26{ }^{\circ} \mathrm{C}$ and $70 \%$ relative humidity, according to the nearest weather station $(20 \mathrm{~km})$.

Of all the collected larvae, only eight pre-pupae and two larvae arrived alive to the lab. Both larvae were third instar (L3) of the same morphotype. The larvae were kept with rotten meat in a BOD incubator at $26.5^{\circ} \mathrm{C}$ and $70 \%$ relative humidity, since this was the temperature at the day of collection, according to the nearest weather station. The pre-pupae were kept in the same BOD incubator.

From the eight pre-pupae, seven adults emerged, between 24 and 25 March 2010, and were identified as Chrysomya albiceps. From the two L3, two adults emerged, between 26 and 29 March 2010, and were identified as Hemilucilia segmentaria. All the identifications were based on Mello (2003) and de Carvalho \& Mello-Patiu (2008).

According to the data collected from the literature, the average duration of the development of $C$. albiceps (egg-adult) is 264 hours ( 11 days) (unpublished data). For H. segmentaria, this period it is 310 hours, or 12.90 days (Thyssen 2005) (Table I).

Table I. Average duration (in hours) of the total development time (eggadult) and each immature stage of Chrysomya albiceps and Hemilucilia segmentaria.

\begin{tabular}{lcc}
\hline \multicolumn{1}{c}{ Stages } & ${\text { Chrysomya } \text { albiceps }^{1}}$ & Hemilucilia segmentaria $^{2}$ \\
\hline Egg & 12 & 12 \\
L1 & 16 & 12 \\
L2 & 20 & 24 \\
L3 & 68 & 96 \\
Pre-pupa & 58 & 24 \\
Pupa & 90 & 136 \\
\hline Total & 264 & 310
\end{tabular}

${ }^{1}$ Data collected at the Núcleo de Entomologia Forense from the Universidade de Brasília, at $26{ }^{\circ} \mathrm{C}$ and $75 \%$ RU (data not published). ${ }^{2}$ Data collected at 25 ${ }^{\circ} \mathrm{C}$ and $70 \%$ RU (Thyssen 2005). Egg: period between egg laying and egg hatching; L1: first instar larva; L2: second instar larva; L3: third instar larva.

Actually, the best alternative to estimate the minimum PMI is the period of insect activity (PIA) (Amendt et al. 2007) on the corpse, instead of estimations based on temperature (accumulated degree hours or accumulated degree days) and/or larval length. The value of PIA indicates when the insect colo- nization took place, often referred to as the minimum PMI. The PIA was estimated as being equal to the age of the oldest immature collect on the corpse. We estimated their age at the time they were collected as the difference between the total development time and the time that was necessary for them to develop into adults in our laboratory (Amendt et al. 2007).

For C. albiceps, PIA $=264 \mathrm{~h}-96 \mathrm{~h}=168 \mathrm{~h}$ or 7 days. For $H$. segmentaria, PIA $=310 \mathrm{~h}-144 \mathrm{~h}=166 \mathrm{~h}$ or 6.9 days. As the larvae reached the laboratory three days after collection, we can estimate that they were using the body as a resource for about four days. Therefore, the most probable day of oviposition for both species was between 13 and 14 March 2010 (Fig. 1).

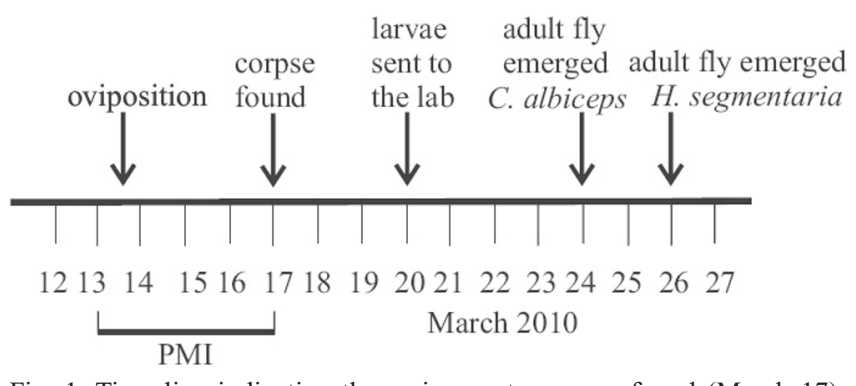

Fig. 1. Time line indicating the main events: corpse found (March 17); immature arrived at the lab (March 20); adult fly of Chrysomya albiceps emerged at the lab (March 24); adult fly of Hemilucilia segmentaria emerged at the lab (March 26); estimated minimun PMI (March 13).

Some insect larvae use corpses as a source of ephemeral resource. They complete their development feeding on the body, often by more than a generation. This phenomenon, called succession, can be observed for some insect's species, including flies, but is not a rule for the tropical fauna due to intrinsic environmental factors (e.g. heat, humidity), that can accelerate or retard the decomposition of the corpse.

We did not estimate the PMI based on cumulative degree-hours or degree-days due the absence of measurements of air and corpse temperatures at the crime scene (Greenberg $\&$ Kunich 2002). Since the nearest wheater station was 20 $\mathrm{km}$ away from the crime scene and the humidity and temperature vary widely in the Cerrado (range of $10.3{ }^{\circ} \mathrm{C}$ and $44 \% \mathrm{RU}$ on the day that the body was discovered), we discarded the use of cumulative degree-hours and/or degreedays in order to estimate the PMI in this case. Therefore, estimation of the PMI based on the period of insect activity (PIA) on the corpse seemed to be the best alternative (Catts 1990).

The post-embryonary development of $C$. albiceps has been extensively studied in the laboratory, as it is a species of great value for forensic entomology in urban and rural areas in Brazil (Linhares 1981; Souza \& Linhares 1997; Biavati et al. 2010). This species has a preference for colonizing decomposing animal organic matter and is known for its voracious appetite, being a predator of larvae of other flies as well as a cannibal during the third instar (Faria \& Godoy 2001, Faria et al. 2007). 
H. segmentaria is an endemic species from Central and South America (Dear 1985), and characteristic of forest areas, being rarely collected in urban environments (Linhares 1981; Ferreira 1983; Paraluppi \& Castellón 1994; Ferreira \& Barbola 1998; Rodrigues-Guimarães et al. 2007). It is a necrophagous species, and its larvae usually feed on decaying animal matter and feces (Linhares 1981; Ferreira \& Barbola 1998; Thyssen \& Linhares 2007). This is the first time that this species was used to estimate the minimum PMI in a forensic investigation, and the estimated minimum PMI through its biology was the same as the one estimated by $C$. albiceps, a species that is widely used in cases of forensic entomology in Brazil.

\section{ACKNOWLEDGMENTS}

The authors thank the Conselho Nacional de Desenvolvimento Científico e Tecnológico/CNPq (CK and JRPL) and the Fundação de Amparo à Pesquisa do Distrito Federal/FAPDF (JRPL) for the grant and financial support. We are also grateful to Nelson Papavero (MZUSP) for reviewing the manuscript and Karine Brenda Barros Cordeiro for her helping in editing the timeline figure.

\section{REFERENCES}

Amendt, J.; C. P. Campobasso; E. Gaudry; C. Reiter; H. N. LeBlanc \& M. J. R. Hall. 2007. Best practice in forensic entomology - standards and guidelines. International Journal of Legal Medicine 121: 90-104.

Biavati, G. M.; F. H. De A. Santana \& J. R. Pujol-Luz. 2010. A Checklist of Calliphoridae Blowflies (Insecta, Diptera) Associated with a Pig Carrion in Central Brazil. Journal of Forensic Sciences 55: 1603-1606.

Catts, E. P. 1990. Analyzing Entomological Data, p. 124-137. In: E. P. Catts \& N. H. Haskell. Entomology and death: a procedural guide. Clemson, Joyce's Print Shop, 182 p.

Catts, E. P. \& N. H. Haskell. 1990. Entomology and death: a procedural guide. Clemson, Joyce's Print Shop, $182 \mathrm{p}$.

Dear, J. P. 1985. A revision of the new world Chrysomyini (Diptera: Calliphoridae). Revista Brasileira de Zoologia 3: 109-169.

de Carvalho, C. J. B. \& C. A. de Mello-Patiu. 2008. Key to the adults of the most common forensic species of Diptera in South America. Revista Brasileira de Entomologia 52: 390-406.

Faria, L. D. B. \& W. A. C. Godoy. 2001. Prey Choice by Facultative Predator Larvae of Chrysomya albiceps (Diptera: Calliphoridae). Memórias do Instituto Oswaldo Cruz 96: 875-878.

Faria, L. D. B.; C. Reigada; L. A. Trinca \& W. A. C. Godoy. 2007. Foraging behaviour by an intraguild predator blowfly, Chrysomya albiceps (Diptera, Calliphoridae). Journal of Ethology 25: 287-294.

Ferreira, J. M. M. 1983. Sinantropia de Calliphoridae (Diptera) em Goiânia, Goiás. Revista Brasileira de Biologia 43: 199-210.
Ferreira, M. J. M \& I. F. Barbola. 1998. Sinantropia de Califorídeos (Insecta, Diptera) de Curitiba, Paraná, Brasil. Revista Brasileira de Biologia 58: 203-209.

Gerber, P. 1987. Playing dice with expert evidence: the lessons to emerge from Regina v. Chamberlain. Medical Journal of Australia 174: 243247.

Goddard, J. \& P. K. Lago. 1985. Notes on blow fly (Diptera: Calliphoridae) succession on carrion in northern Mississipi. Journal of Entomological Science 20: 312-317.

Greenberg, B. \& J. C. Kunich. 2002. Entomology and the Law: flies as forensic indicators. Cambridge, University Press, xiii+306 p.

Keh, B. 1985. Scope and applications of forensic entomology. Annual Review of Entomology 30: 137-154.

Linhares, A. X. 1981. Synanthropy of Calliphoridae and Sarcophagidae (Diptera) in the city of Campinas, São Paulo, Brazil. Revista Brasileira de Entomologia 25: 189-215.

Mann, R. W.; W. M. Bass \& L. Meadows. 1990. Time since death and decomposition of the human body: variables and observations in case and experimental field studies. Journal of Forensic Sciences 35: 103111.

Mello, R. P. de. 2003. Chave para a identificação das formas adultas das espécies da família Calliphoridae (Diptera, Brachycera, Cyclorrhapha) encontradas no Brasil. Entomología y Vectores 10: 255-268.

Paraluppi, N. D. \& E. G. Castellón. 1994. Calliphoridae (Diptera) em Manaus: I levantamento taxonômico e sazonalidade. Revista Brasileira de Entomologia 38: 661-668.

Pujol-Luz, J. R.; L. C. Arantes \& R. Constantino. 2008. Cem anos da entomologia Forense no Brasil (1908-2008). Revista Brasileira de Entomologia 54: 485-492.

Rodrigues-Guimarães, R.; R. R. Guimarães; H. M. Barros; R. W. Carvalho \& G. E. Moya-Borja. 2007. Abundância Absoluta, Relativa e Sazonalidade de Dípteros Califorídeos (Diptera, Calliphoridae) na Baixada Fluminense, Rio de Janeiro, Brasil. Revista de Ciência e Tecnologia 7: 50-63.

Smith, K. G. V. 1986. A Manual of Forensic Entomology. Ithaca, Cornell University Press, 205 p.

Souza, A. M. de \& A. X. Linhares. 1997. Diptera and Coleoptera of potential forensic importance in Southeastern Brazil: relative abundance and seasonality. Medical and Veterinary Entomology 11: 8-12.

Stevens, J. R. 2003. The evolution of myiasis in blowflies (Calliphoridae). International Journal of Parasitology 33: 1105-1113.

Thyssen, P. J. 2005. Caracterização das formas imaturas e determinação das exigências térmicas de duas espécies de califorídeos (Diptera) de importância forense [thesis]. Campinas, UNICAMP, xiv $+102 \mathrm{p}$.

Thyssen, P. J. \& A. X. Linhares. 2007. First description of the immature stages of Hemilucilia segmentaria (Diptera: Calliphoridae). Biological Research 40: 271-280.

Vargas, J. \& D. M. Wood. 2010. Calliphoridae, p. 1297-1304. In: B. V. Brown, A. Borkent, J. M. Cumming, D. M. Wood, N. E. Woodley, \& M. A. Zumbado (eds.). Manual of Central American Diptera. Vol. 2. Ottawa, NCR Research Press, 728 p.

Wall, R. \& M. L. Warnes. 1994. Responses of the sheep blowfly Lucilia sericata to carrion odour and carbon dioxide. Entomologia experimentalis et applicata 73 : $239-246$. 